\title{
Variants of East African cassava mosaic virus and Its Distribution in Double Infections with African cassava mosaic virus in Nigeria
}

F. O. Ogbe, International Institute of Tropical Agriculture (IITA), Ibadan, Nigeria and National Root Crops Research Institute, Umudike, Umuahia, Nigeria; G. Thottappilly, IITA and Mahyco Research Foundation, Hyderabad, India; A. G. O. Dixon, IITA; G. I. Atiri, Department of Crop Protection and Environmental Biology, University of Ibadan, Ibadan, Nigeria; and H. D. Mignouna, IITA

\begin{abstract}
Ogbe, F. O., Thottappilly, G., Dixon, A. G. O., Atiri, G. I., and Mignouna, H. D. 2003. Variants of East African cassava mosaic virus and its distribution in double infections with African cassava mosaic virus in Nigeria. Plant Dis. 87:229-232.

In a survey for cassava mosaic begomoviruses conducted in 1997 and 1998 in Nigeria, East African cassava mosaic virus (EACMV) was detected by the polymerase chain reaction together with African cassava mosaic virus (ACMV) in 27 out of 290 cassava leaf samples of infected plants from 254 farmers' fields in five agroecological zones. One plant was infected with EACMV only. Five variant isolates of EACMV were observed based on their reactions to primers that could detect Cameroonian and East African strains of EACMV. Isolates of variants 1 and 3 occurred mostly in the derived or coastal and southern Guinea savannahs, while variants 4 and 5 predominated in the humid forest region. Isolates of variant 2 were widely distributed across the three agroecologies. EACMV was not detected in the northern Guinea savannah and arid and semiarid zones. Most doubly infected plants showed more severe symptoms than plants with single infection. Occurrence of EACMV variants together with ACMV detection and information about their distribution in Nigeria could be used for the selection of cassava clones in cassava mosaic disease resistance programs.
\end{abstract}

East African cassava mosaic virus (EACMV) occurs throughout sub-Saharan Africa $(6,12,13,14,16)$. The virus, in combination with African cassava mosaic virus (ACMV), is the major cause of cassava mosaic disease in sub-Saharan Africa, with attendant yield reduction of between 20 and $95 \%(15,18)$ of cassava, which provides staple food for over 200 million people in the region (11). The two viruses belong to the family Geminiviridae, genus Begomovirus (10).

Double infection of cassava with EACMV and ACMV has been documented in Tanzania (8), Cameroon (7), and Côte d'Ivoire (14), with most plants exhibiting severe disease symptoms. The widespread virus epidemic in Uganda resulted from mixed infections of ACMV and EACMV$\mathrm{Ug}(8)$.

Strains of EACMV occur. Hong et al. (9) distinguished a Kenyan strain of the virus from ACMV and Indian cassava mosaic virus (ICMV). This strain later was

Corresponding author: F. O. Ogbe

E-mail: fogbe@danforthcenter.org

This was part of a Ph.D. research program of F. O. Ogbe, which was funded by IITA, Nigeria through the award of a Research Fellowship.

Accepted for publication 25 August 2002.

Publication no. D-2002-1218-01R

(C) 2003 The American Phytopathological Society reported to occur also in Tanzania and Malawi (20). The authors (20) reported additional strain of the virus in Malawi. Zhou et al. (19) provided evidence of interspecific recombination of DNAs of ACMV and EACMV to give rise to a strain of EACMV in Uganda (EACMV-Ug). A different strain of the virus also was reported in Cameroon (9).

This study was a follow up of the first report of the occurrence of EACMV in Nigeria (13), which led to the collection of more cassava leaf samples in order to determine the distribution of the virus in the country and to test for variability among its isolates. The variations reported here were based on polymerase chain reaction (PCR) tests. In the absence of DNA sequence data for definite molecular characterization, contrasting isolates are regarded as variants of EACMV instead of strains. Their distribution in Nigeria, mostly in mixed infections with ACMV, is presented. The information could be utilized in the screening of cassava genotypes for resistance to cassava mosaic disease (CMD) on-station and at suitable agroecological sites.

\section{MATERIALS AND METHODS}

Collection of virus-infected cassava leaves. In 1997 and 1998, young cassava leaves with characteristic CMD symptoms were collected from 316 plants in 254 farmers' fields located at intervals of between 10 and $20 \mathrm{~km}$. The latitude and longitude of each farm were recorded using
Global Positioning System equipment (Magellan GPS, model Nav 5000 DLX). Symptom severity was rated as described by Terry (17). Leaf samples were stored in plastic bags over ice until they were stored at $-20^{\circ} \mathrm{C}$ in the laboratory.

Indexing for cassava mosaic begomoviruses using PCR. Total DNA was extracted from leaf samples using the method described by Dellaporta et al. (4). The following pairs of primers were used for detection: ACMV-AL1/F/ACMVAR0/R for the detection of open reading frames (ORFs) AC1/AV2 of ACMV, UV$\mathrm{AL} 1 / \mathrm{F} / \mathrm{R}$ for ORF AC1 of most EACMV strains, UV-AL3/F/UV-AL1/R2 for ORFs AC3/AC1 of most EACMV strains, and UV-AL1/F/ACMV-CP/R3 for ORFs AC1/AV1 specific for Ugandan EACMV strain (EACMV-Ug) (19); UV-AL1/ F/EACMV-CP/R for ORFs AC1/AV1 specific for Kenyan (EACMV-K) and Tanzanian (EACMV-T) strains (8); VNF003/ 004 for ORF AV1 (CP), VNF031/032 for ORFs AC2/AC3, and EB03/04 for ORFs BV1/BC1 used for a Cameroonian strain (7); and ICMV-F1/R1 for the intergenic region and ORF AV2 of ICMV (9). The reaction mixtures $(26.4 \mu \mathrm{l})$ contained $1 \times$ Thermobuffer, $2.4 \mathrm{mM} \mathrm{MgCl}$, Tween-20 at $5.2 \mathrm{mg} / \mathrm{ml}, 190 \mu \mathrm{M}$ dNTPs, $0.2 \mathrm{pM}$ of each forward and reverse primer, 2 units of Taq DNA polymerase (Promega, Madison, WI), and $10 \mathrm{ng}$ of DNA sample. The negative controls were the buffer used for DNA extraction (4) and the DNA of a healthy leaf obtained from cassava plant derived from meristem tip culture in the International Institute of Tropical Agriculture (IITA) Tissue Culture Laboratory, IITA, Ibadan, Nigeria. Positive controls were not available. The thermal cycles were carried out in the Perkin-Elmer GeneAmp PCR system, model 9600 (19). The PCR products were separated by electrophoresis in agarose gel at $10 \mathrm{mg} / \mathrm{ml}$ at 100 volts for about $1.5 \mathrm{~h}$. The DNA bands were visualized, following ethidium bromide staining, under UV light and photographs were taken using gel documentation and analysis system computer software (model UVP GDS 8000, Ultra-violet Product Ltd., Cambridge, UK). Determination of EACMV variant was based on the reactions of EACMV-positive samples with primers that could detect Cameroonian, Kenyan, and Ugandan strains. 
Distribution of EACMV in Nigeria. In order to relate the distribution of EACMV to ACMV and to agroecologies, the latitude and longitude coordinates of the survey samples were superimposed on the agroecological map of Nigeria using a computer software ArcView ver. 3.1 (Environmental Systems Research Institute, Inc, Redlands, CA), which was supplied as
IITA Geographical Information Systems Lab 2000. The agroecologies were humid forest, derived or coastal, southern Guinea, and northern Guinea savannahs and arid and semiarid land.

\section{RESULTS}

Diagnosis of viruses by PCR. Of 316 leaf samples, 26 were discarded upon arri-

Table 1. Cassava mosaic disease (CMD) severity on cassava genotypes singly and doubly infected by East African cassava mosaic virus (EACMV) and African cassava mosaic virus (ACMV) in farmers' fields under different agroecologies in Nigeria ${ }^{y}$

\begin{tabular}{lccc}
\hline & \multicolumn{3}{c}{ Mean CMD severity score } \\
\cline { 2 - 4 } Agroecology & ACMV & EACMV & ACMV + EACMV \\
\hline Humid forest & $3.2 \pm 0.4(100)$ & $\ldots$ & $3.6 \pm 0.5(14)$ \\
Derived or coastal savannah & $3.1 \pm 0.3(102)$ & $3.0(1)$ & $3.4 \pm 0.5(9)$ \\
Southern guinea savannah & $3.0 \pm 0.2(35)$ & $\ldots$ & $4.0 \pm 0.8(4)$ \\
\hline
\end{tabular}

${ }^{y}$ Samples were collected on a diagnostic survey of cassava mosaic begomoviruses in 1997 and 1998 . The double infections were determined by polymerase chain reaction.

${ }^{\mathrm{z}}$ Severity scores ranged from $1=$ no symptoms to $5=$ very severe symptoms (17). Numbers in parenthesis were total samples used for the calculation of mean \pm standard deviation.

val due to poor quality. The remaining 290 samples were positive by PCR for ACMV, except for 1, which reacted positively with EACMV primers. Of 289 samples that reacted with ACMV primers, 27 also were positive for EACMV. None of the 290 samples tested positive to ICMV and EACMV-Ug primers.

Disease severity. Most plants that were infected with both ACMV and EACMV expressed more severe symptoms than those infected by ACMV alone (Table 1). Symptoms were generally moderate on cassava infected by ACMV but a few genotypes expressed severe symptoms. The only shoot bearing EACMV alone also showed moderate symptoms. There was no noticeable influence of agroecologies on the expression of symptoms by infected plants (Table 1).

Ecological distribution of ACMV and EACMV. ACMV occurred in all the farms in the five agroecologies (Fig. 1). The only

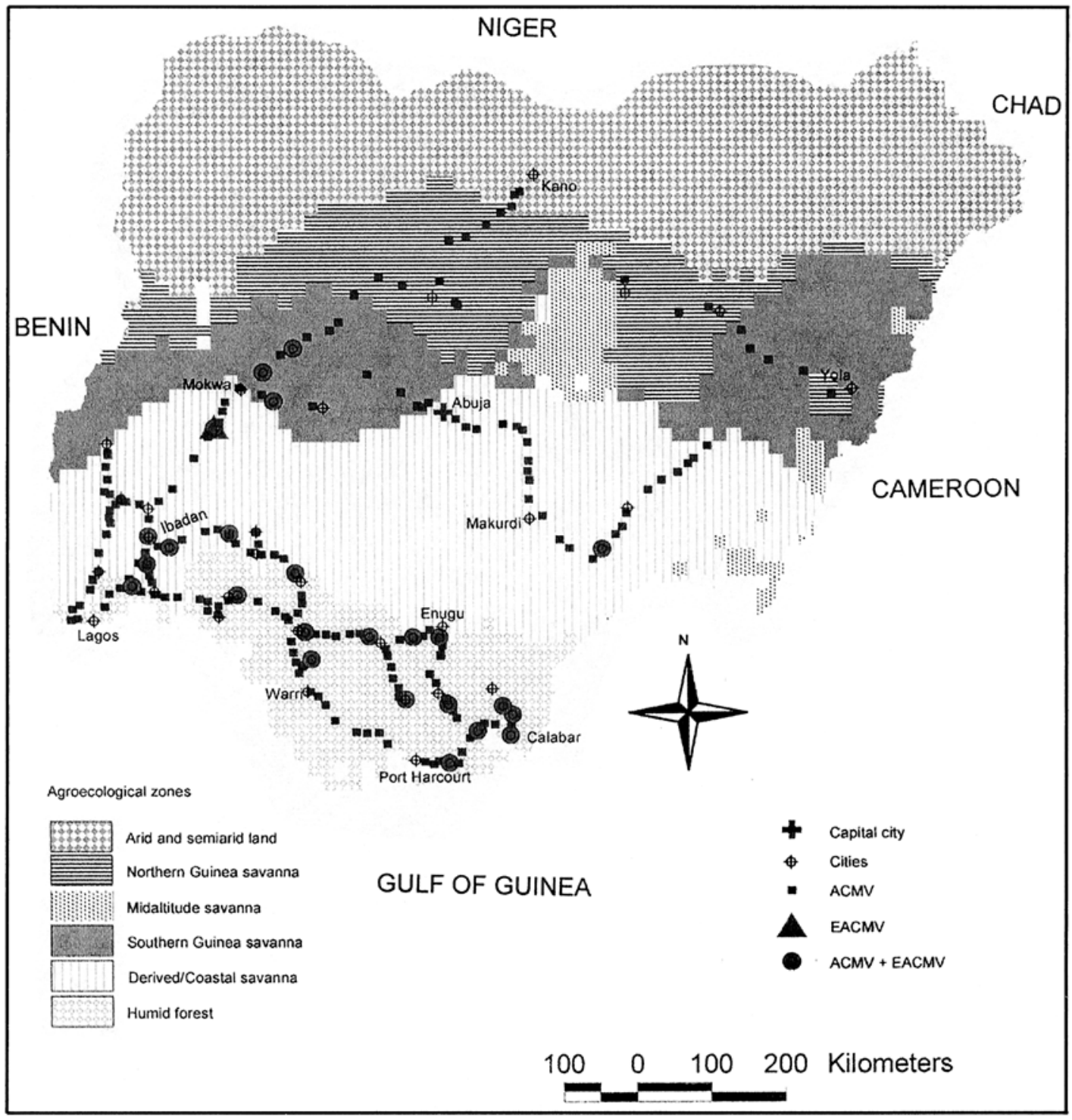

Fig. 1. The distribution of East African cassava mosaic virus (EACMV), African cassava mosaic virus (ACMV), and their double infections in the agroecologies of Nigeria. EACMV was detected in $8 \%$ of the samples; all except one were double infections with ACMV and all were collected only from the humid forest, derived or coastal, and southern Guinea savannahs. ACMV occurred in all the cassava farms and agroecologies visited. 
isolate of EACMV was collected in Ogbena village in the northwestern part of the derived or coastal savannah, about $198 \mathrm{~km}$ from Ibadan along the Ibadan-Mokwa road. In the same farm, ACMV and EACMV were detected in different shoots of the same plant. Of the plants with double virus infections, $52 \%$ occurred in the humid forest and were uniformly distributed; $33 \%$ were in the derived or coastal savannah, with more occurring in the west rather than in the east; and $15 \%$ were present in the western part of southern Guinea savannah, but not in the eastern part. EACMV was not detected in the northern Guinea savannah and the arid and semiarid land agroecologies (Fig. 1).

Variants of EACMV. All the EACMV primers except UV-AL1/F1/ACMV-CP/R3 (Table 2, column F), which were specific for a Ugandan strain, detected at least some of the Nigerian isolates. Primer pair VNF003/004 (Table 2, column A) detected 19 of the 28 isolates, UV-AL1/F1/R1 (Table 2, column E) detected 20 isolates, and UV-AL1/F1/EACMV-CP/R (Table 2, column G) tested positive for eight isolates. Primers EB03/04 (Table 2, column C) detected five isolates. Primer pairs VNF031/032 and UV-AL3/F/UV-AL1/R2 (Table 2, columns B and D, respectively) tested positive for all the Nigerian isolates.

Based on results for primers VNF003/004 for ORF AV1 (CP), UVAL1/F1/R1 for ORF AC1, and UV-AL1/F1

Table 2. Representative reactions of Nigerian isolates of East African cassava mosaic virus (EACMV) with different EACMV primers

\begin{tabular}{llllllll}
\hline & \multicolumn{7}{c}{ Pairs of EACMV primers } \\
\cline { 2 - 8 } Isolate & A & B & C & D & E & F & G \\
\hline 7 & + & + & - & + & + & - & + \\
56 & + & + & - & + & + & - & - \\
112 & + & + & + & + & + & - & + \\
123 & - & + & - & + & - & - & - \\
157 & - & + & - & + & + & - & - \\
310 & - & + & + & + & - & - & - \\
313 & + & + & + & + & - & - & + \\
\hline
\end{tabular}

${ }^{\mathrm{z}} \mathrm{A}=\mathrm{VNF} 003 / 004$ for open reading frame (ORF) AV1 (CP), B = VNF031/032 for ORFs AC2/AC3, and $\mathrm{C}=\mathrm{EB} 03 / 04$ for ORFs BV1/BC1 all designed for the Cameroonian strain (7); $\mathrm{D}=\mathrm{UV}$ AL3/F/UV-AL1/R2 for ORFs AC3/AC1 and $\mathrm{E}=\mathrm{UV}-\mathrm{AL} 1 / \mathrm{F} 1 / \mathrm{R} 1$ for ORF AC1, both for most strains of EACMV; $\mathrm{F}=\mathrm{UV}-\mathrm{AL} 1 / \mathrm{F} 1 / \mathrm{ACMV}-\mathrm{CP} / \mathrm{R} 3$ for ORFs AC1/AV1 specific for Ugandan strain (19); G = UV-AL1/F1/EACMV-CP/R for ORF AC1/AV1 of the Kenyan strain and to differentiate it from the Ugandan strain (8); + = positive and $-=$ negative results.

\section{DISCUSSION}

This was the first extensive survey for EACMV in Nigeria. Failure to detect either ICMV or EACMV-Ug could indicate either absence of these viruses in Nigeria, or extremely low incidence. Most EACMV isolates occurred together with ACMV (Fig. 1), and such double infections also have been observed in Côte d'Ivoire (14), Cameroon (7), and western Tanzania (8). However, infection of cassava by EACMV alone is common in eastern Tanzania and Kenya, and throughout Madagascar and Malawi (16), whereas EACMV and ACMV occur together in the western parts of East African countries, across to West Africa.

Several scenarios could explain the low incidence (28 of 290) of EACMV. The virus might not have been present in Nigeria originally, when cassava was introduced into West Africa in the sixteenth century (3). It is possible that EACMV was introduced from coastal areas of East Africa, including Madagascar, where the virus is predominant (16). It is known that cassava clones were transferred from coastal Kenya and Madagascar to Côte d'Ivoire (5) for research purposes and, although such transfers are officially strictly regulated, EACMV could have been introduced accidentally to West Africa through either weaknesses in quarantine procedures or through unofficial germ plasm introductions.

Another possible reason for the low incidence of EACMV in Nigeria could be due to inefficient spread of the virus by the whitefly vector. Differences in virus transmission are known among biotypes of Bemisia tabaci Gennadius (2). There is no information, however, on the efficiency of whitefly vector transmission for EACMV in Nigeria. Nevertheless, despite the low occurrence, the virus distribution was uniform, particularly in the humid forest agroecology examined here (Fig. 1).

The apparent absence of EACMV in the northern Guinea savannah, arid, and semiarid regions could not be readily explained. It might be due to low vector population with attendant low disease spread (1).

The severe symptoms caused by mixed EACMV and ACMV infections (Table 1)

Table 3. Variants of Nigerian East African cassava mosaic virus (EACMV) isolates as determined by polymerase chain reaction using primers that could detect Cameroonian and East African strains of the virus and the distribution of the variants in the agroecologies of Nigeria

\begin{tabular}{|c|c|c|c|c|}
\hline \multirow[b]{2}{*}{ Variant } & \multicolumn{3}{|c|}{ Primer pairsw } & \multirow[b]{2}{*}{ Distribution } \\
\hline & $\begin{array}{l}\text { VNF003 } \\
\text { VNF004 }^{x}\end{array}$ & $\begin{array}{l}\text { UV-AL1/F1 } \\
\text { UV-AL1/Ry }\end{array}$ & $\begin{array}{c}\text { UV-AL1/F1 } \\
\text { EACMV-CP/R }\end{array}$ & \\
\hline 1 & + & + & + & Mostly in the derived or coastal and southern Guinea savannahs \\
\hline 2 & + & + & - & Widely distributed in the humid forest, derived or coastal, and southern Guinea savannahs \\
\hline 3 & + & - & + & Derived or coastal savannah \\
\hline 4 & - & + & - & Humid forest \\
\hline 5 & - & - & - & Mostly in the humid forest \\
\hline
\end{tabular}

${ }^{\mathrm{w}}$ Results: $+=$ positive and $-=$ negative.

x Primers designed for open reading frame (ORF) AV1 (CP) of Cameroonian strain (7).

y Primers for ORF AC1 of most strains of EACMV (19).

${ }^{\mathrm{z}}$ Primers for ORFs AC1/AV1 of the Kenyan strain and to differentiate it from the Ugandan strain (8) 
M $1234567891011121314 M$

$677 \mathrm{bp}$

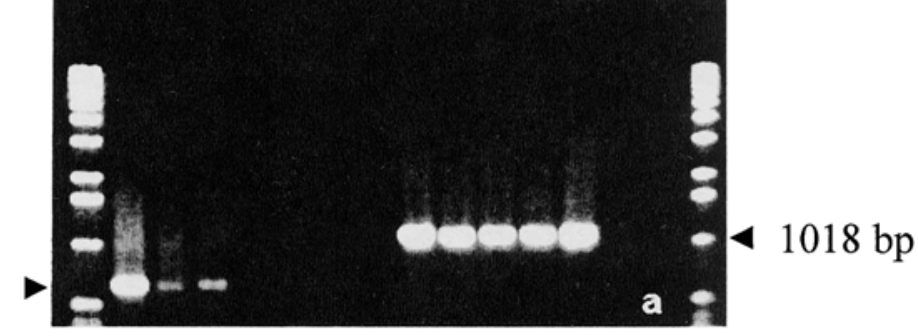

M1516171819202122 $232425262728 \mathrm{M}$

$506 \mathrm{bp}$

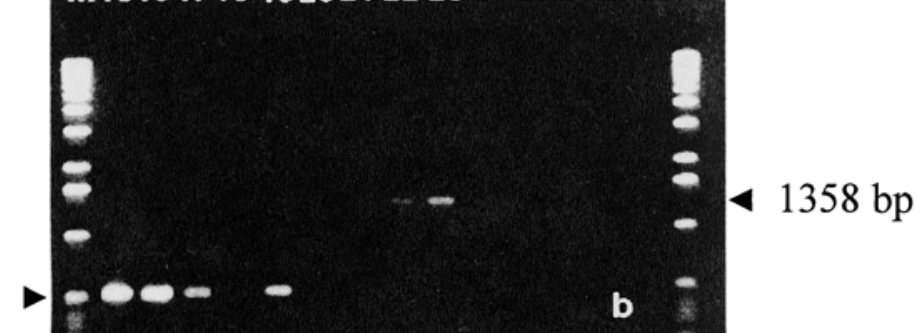

Fig. 2. Gel electrophoresis of DNA fragments of representative Nigerian isolates of the three most abundant variants of East African cassava mosaic virus (EACMV) amplified in polymerase chain reaction by four pairs of primers. Lanes 1-5 contained DNA of isolates 7, 13 (variant 1), 109 (variant 2), 123, and 310 (variant 5), respectively. Lane $6=$ DNA of healthy leaf, lane $7=$ buffer. This arrangement was repeated in lanes $8-14,15-21$, and 22-28. The samples were tested by the following primers: lanes 1-7 = VNF003/004 designed for open reading frame (ORF) AV1 (CP) of Cameroonian strain (7); lanes 8-14 = UV-AL3/F/UV-AL1/R2 for ORFs AC3/AC1 of most strains of EACMV; lanes $15-21=$ UV-AL1/F1/R1 for ORF AC1 of most strains of EACMV (19); lanes 22-28 = UVAL1/F1/EACMV-CP/R for ORFs AC1/AV1 of Kenyan strain and to differentiate it from Ugandan strain (8). $\mathrm{M}=1-\mathrm{kb}$ DNA ladder.

were similar to those reported in Cameroon (7), Côte d'Ivoire (14), and Tanzania (8). Severe symptoms also were observed in cassava infected with both ACMV and EACMV-Ug (8). Mixed infections have been implicated in viral DNA recombination that gave rise to EACMV-Ug (19); therefore, it might be expected that new variants of cassava begomoviruses will be found in Nigeria.

Cameroonian EACMV strain arose from recombination at the ORFs AC2/AC3 (7). The fact that all Nigerian isolates reacted with primers VNF031/032 (Table 3), which amplify ORFs AC2/AC3 for the Cameroonian strain, suggests that Nigerian genotypes are similar to those from Cameroon and, furthermore, Nigerian isolates also may be recombinants of EACMV.

Occurrence of EACMV variants in $\mathrm{Ni}$ geria was in agreement with the findings in other African countries $(7,14,19,20)$. The observation that most Nigerian isolates reacted as a typical Cameroonian strain (Tables 2 and 3) supports the view of Pita et al. (14) that the Cameroonian EACMV strain is predominant in West Africa. However, the lack of amplification of most Nigerian isolates by primers used to detect the Cameroonian DNA-B component (7; Table 2) suggests that the similarity between the Nigerian and Cameroonian isolates is mainly with the DNA-A component. Therefore, Nigerian isolates may differ somewhat from those in Cameroon.
Variant 5 differs from some Cameroonian and East African isolates based on differential amplification with the $\mathrm{CP}$ primers that detected the Cameroonian strain and the $\mathrm{AC} 1$ and $\mathrm{CP}$ primers that detected the Kenyan strain but not variant 5 (Table 3; Fig. 2), which suggests that asyet-uncharacterized genotypes occur in Nigeria.

Occurrence of EACMV variants in $\mathrm{Ni}$ geria and access to cassava plants harboring infections by both ACMV and EACMV, together with severe symptoms that also characterize such infections in the major cassava-growing areas of differing agroecologies in the country, are important for programs involved in breeding of resistant cassava genotypes.

\section{ACKNOWLEDGMENTS}

We thank F. M. Quin, former Director of Crop Improvement Division of the Institute, for assistance in securing the Fellowship of F. O. Ogbe; J. d'A. Hughes, IITA, Nigeria, for offering useful suggestions during the course of the research; and R. Okechukwu, IITA, Nigeria, for preparing the map of Nigeria.

\section{LITERATURE CITED}

1. Akano, A. O., Atiri, G. I., Ng, S. Y. C., and Asiedu, R. 1997. Effect of African cassava mosaic disease on growth and yield components of virus-tested cassava genotypes derived from meristem culture in early and late planting periods in three agroecologies of Nigeria. Afr. J. Root Tuber Crops 2:44-48.

2. Bedford, I. D., Briddon, R. N., Brown, J. K., Rosell, R. C., and Markham, P. G. 1994.
Geminivirus transmission and biological characterization of Bemisia tabaci (Gennadius) biotypes from different geographic regions. Ann. Appl. Biol. 125:31-325.

3. Carter, S. E., Fesco, L. O., Jones, P. G., and Fairbairn, J. N. 1995. Introduction and diffusion of cassava in Africa. Res. Guide No. 49, IITA, Ibadan, Nigeria.

4. Dellaporta, S. L., Woods, J., and Hicks, J. B. 1983. A plant DNA mini-preparation: version II. Plant Mol. Biol. Rep. 1:19-21.

5. Fauquet, C., and Fargette, D. 1990. African cassava mosaic virus: etiology, epidemiology and control. Plant Dis. 74:404-411.

6. Fondong, V. N., Pita, F. S., Rey, C., Beachy, R. N., and Fauquet, C. M. 1998. First report of the presence of East African cassava mosaic virus in Cameroon. Plant Dis. 82:1172.

7. Fondong, V. N., Pita, F. S., Rey, M. E. C., de Kochko, A., Beachy, R. N., and Fauquet, C. M. 2000. Evidence of synergism between African cassava mosaic virus and a new doublerecombinant geminivirus infecting cassava in Cameroon. J. Gen. Virol. 81:287-297.

8. Harrison, B. D., Zhou, X., Otim-Nape, G. W., Liu, Y., and Robinson, D. J. 1997. Role of a novel type of double infection in the geminivirus-induced epidemic of severe cassava mosaic in Uganda. Ann. Appl. Biol. 131:437448.

9. Hong, Y. G., Robinson, D. J., and Harrison, B. D. 1993. Nucleotide sequence evidence for the occurrence of three distinct whiteflytransmitted geminiviruses in cassava. J. Gen. Virol. 74:2437-2443.

10. Mayo, M. A., and Pringle, C. R. 1998. Virus taxonomy-1997. J. Gen. Virol. 79:649-657.

11. Nweke, F. I., and Lynam, J. K. 1997. Cassava in Africa. Afr. J. Root Tuber Crops 2:10-13.

12. Offei, S. K., Owuna-Kwakye, M., and Thottappilly, G. 1999. First report of East African cassava mosaic begomovirus in Ghana. Plant Dis. 83:877.

13. Ogbe, F. O., Atiri, G. I., Robinson, D., Winter, S., Dixon, A. G. O., Quin, F. M., and Thottappilly, G. 1999. First report of East African cassava mosaic begomovirus in Nigeria. Plant Dis. 83:398.

14. Pita, J. S., Fondong, V. N., Sangeré, A., Kokora, R. N. N., and Fauquet, C. M. 2001. Genomic and biological diversity of the African cassava geminiviruses. Euphytica 120: 115-125.

15. Seif, A. A. 1982. Effect of cassava mosaic virus on yield of cassava. Plant Dis. 66:661662.

16. Swanson, M. M., and Harrison, B. D. 1994. Properties, relationships and distribution of cassava mosaic geminiviruses. Trop. Sci. 34:15-25.

17. Terry, E. R. 1975. Description and evaluation of cassava mosaic disease in Africa. Pages 5354 in: The International Exchange and Testing of Cassava Germ Plasm in Africa. E. R. Terry and R. MacIntyre, eds. IITA, Ibadan, Nigeria,.

18. Terry, E. R., and Hahn, S. K. 1980. The effect of cassava mosaic disease on growth and yield of a local and an improved variety of cassava. Trop. Pest Manage. 26:34-37.

19. Zhou, X., Liu, Y., Calvert, L., Munoz, C., Otim-Nape, G. W., Robinson, D. J., and Harrison, B. D. 1997. Evidence that DNA-A of a geminivirus associated with severe cassava mosaic disease in Uganda has arisen by interspecific recombination. J. Gen. Virol 78:2101-2111.

20. Zhou, X., Robinson, D. J., and Harrison, B. D. 1998. Types of variation in DNA-A among isolates of East African cassava mosaic virus from Kenya, Malawi and Tanzania. J. Gen. Virol. 79:2835-2840. 